No. 04

\title{
DXA による小児期の除脂肪量の発育に関する検討
}

\author{
鳥居 俊（早稲田大学スポーツ科学学術院） \\ 小児，除脂肪量，DXA
}

【緒言】小児期の発育に伴う筋量の変化についての検討はこれまでにあまり行われていない。従来は 超音波断層法やインピーダンス法による測定をもとにしている検討が主であるが、DXA 法を用いた検 討も少数ながら見られる。

本研究では DXA 法を用いて小児の除脂肪量を算出し、特に四肢の除脂肪量の発育変化を横断的に 検討した。

【方法】小学校 1 年生から中学校 3 年生までの男児 80 名を対象に DXA 法装置 Delphi A-QDR を用い、 whole body mode で計測し、全身除脂肪量および上肢、下肢除脂肪量を算出した。年齢と、各除脂肪量 の值、全身除脂肪量に対する上肢、下肢除脂肪量の割合との関係を検討した。

【結果】全身除脂肪量、上肢、下肢除脂肪量は発育に伴い増加していた、小学生の間は全身除脂肪量 に対する下肢除脂肪量の割合は有意な増加を示すものの、上肢除脂肪量の割合は変化しなかったが、 中学生以降は上肢除脂肪量の割合も増加した。

【考察】全身および四肢の除脂肪量は発育に伴って増加したが、全身除脂肪量に対する割合の変化に は下肢と上肢で違いが見られ、四肢の発育の様式に違いがあることが示された。

下肢は日常生活動作においても荷重負荷を受けるため、早くから発育変化が生じているのに対して、 上肢は特別な負荷が加わらないためか発育の時期が遅れていた。このような除脂肪量の変化の様式は 骨量の変化とも同様であり、発育の部位差ということができる。

飯田 悠佳子, 高橋 直美, 野間 健佑 (早稲田大学大学院) 江川 陽介 (早稲田大学) 